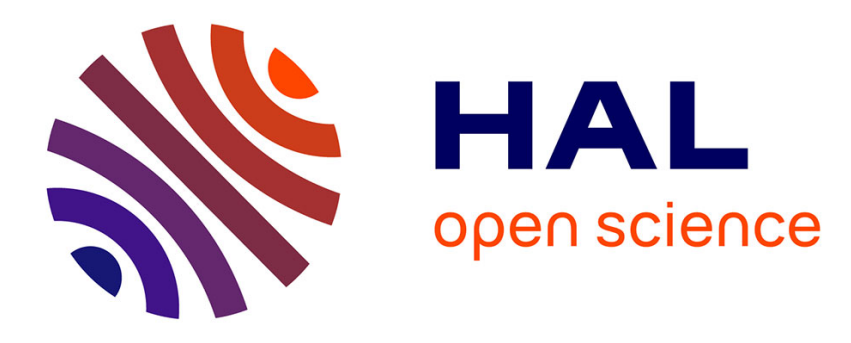

\title{
Politics of Memory in Edith Bruck's Three Visits to Tiszakarád
}

\author{
Andrea Petö
}

\section{To cite this version:}

Andrea Petö. Politics of Memory in Edith Bruck's Three Visits to Tiszakarád. Postmigrantisch gelesen Transnationalität, Gender, Care. Eds. Katrin Huxel / Juliane Karakayali / Ewa Palenga-Möllenbeck / Marianne Schmidbaur / Kyoko Shinozaki / Tina Spies / Linda Supik / Elisabeth Tuider, 2021. hal-03216365

\section{HAL Id: hal-03216365 https://hal.science/hal-03216365}

Submitted on 4 May 2021

HAL is a multi-disciplinary open access archive for the deposit and dissemination of scientific research documents, whether they are published or not. The documents may come from teaching and research institutions in France or abroad, or from public or private research centers.
L'archive ouverte pluridisciplinaire HAL, est destinée au dépôt et à la diffusion de documents scientifiques de niveau recherche, publiés ou non, émanant des établissements d'enseignement et de recherche français ou étrangers, des laboratoires publics ou privés. 


\section{Politics of Memory in Edith Bruck's Three Visits to Tiszakarád}

Andrea Pető

\section{Introduction}

A Holocaust survivor and the author of several books, Edith Bruck was born in Hungary in 1932. Before the Shoah, Edith Bruck lived in Tiszakarád in rural north-eastern Hungary. The village in 1941 had 4694 inhabitants including roughly a dozen orthodox Jewish families, all together 94 people, who worked in agriculture, as butchers, in commerce, or as shop owners and managers. The community did not have a rabbi but observed all the holidays with services held in the local synagogue led by elderly members of the community who studied in yeshivas. The Jewish community was divided along economic lines.Edith Bruck's parents were very poor. Her father was a traveling merchant known for making bad deals, while her mother was a homemaker. Other community members were prosperous enough to finance secondary and even higher education for their children.

Edith Bruck is often called "Signora Auschwitz" in the press: her book with the same title was published in 1999. Only recently, with the English translation of her autobiography, she has received international recognition on a level commensurate with other writers of the Shoah like Elie Wiesel, Imre Kertész, and Primo Levy - just to list a few of those who are by now part of the Holocaust literary canon. The oeuvre of Bruck has recently received scholarly attention(Adalgisa1999, 247-255; Clementi 2008).The fast growing literature on her focuses on issues of Jewish women writers and her choice of language, Italian, her husband's native language, rather than her native Hungarian. In this literature, analysis of Bruck's work as a poet and translator contributes to the study of theories of translation(Balma 2007, 108-113;Balma 2014; Villa

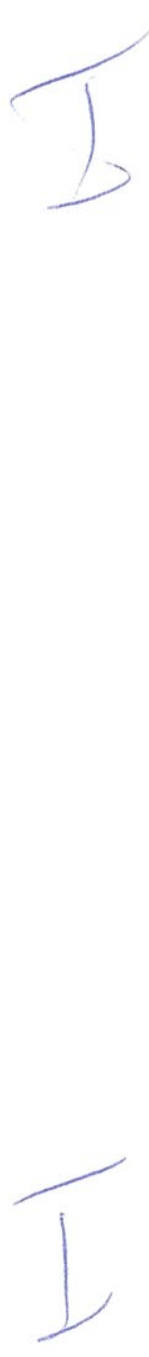


2007, 97-105). This paper investigates a different, previously neglected aspect of her life and work, namely the role her works and testimonies played in constructing memory of the Holocaust in her own native village, Tiszakarád, with an emphasis on the complexities of Jewish-Hungarian relations during and after the Holocaust (Pető 2019).

The present literature focuses on post-migrant societies as multicultural as a result of migration. Post-WWII Hungarian society is an ethnically cleansed society where the surviving Jewish community, the second largest in Europe, tried to blend in as much as possible. In this context the return of a citizen who left the country twice, first by being deported to Auschwitz, and then by escaping to Czechoslovakia, before returning, reveals how society constructs and deals with the 'Other'. The paper also discusses the intersection of class, race and gender in constructing and limiting the agency of a migrant: Edith Bruck who visited her home. The case study describes a society whose anti-Semitism makes it a counter-model to a post-migrant society.

This chapter is based on multiple sources that map different interactions and representations. I yse Bruck's first autobiographical novel, Who Loves you Like This, which established her reputation as a writer. She writes about life in Tiszakarád before the Shoah, the deportation of her family, her return to Tiszakarád and her return to Israel, alija. I use The Visit (1983), a film recording Bruck's return to her village in communist Hungary with a Hungarian film crew. Bruck sought to define herself as a 'moral witness' in the process of making this film. I also conducted two interviews with Bruck in her home in Rome in 2002 (Petô 2007, 243-251), in part based on the politics of making The Visit. Moreover, I used the accounts of five Jewish survivors of the deportations from Tiszakarád whowere interviewed for the Shoah Visual History Archive(VHA) in the late 1990s. Their testimonies were chronologically structured by interview questions the same way as Who Loves you Like This. The accounts describe life in the village prior to the Shoah life, relations between Jews and non-Jews, the roundup and deportation of the Tiszakarád Jews, and the return home of the few survivors after the war before these survivors emigrated from Hungary(The Shoah Visual History Archive Testimonies VHA from here on out) of Erzsébet Grosz, Adel Taub, Biri Goldstein, Ignác Grosz, Irma Nemény). Jews from rural Hungary were eager to emigrate as they were not assimilated and had lost their family members. The Shoah Visual History Archive has its own politics when doing the interviews, therefore in none of the five interviews the interviewer was asking 
further questions regarding that visit and encounters with the villagers who immedifately robbed the houses of the deported Jews in 1944(Pető 2013, 205211;Petố2016, 253-261).

This chapter describes Bruck's two visits back to contextualize her homecoming, which was filmed. In the second section, I analyze the film's production. In the third section, I describe the afterlife of the film and how the status of 'moral witness' can be gendered and consequently questioned in the context of present-day Hungarian politics of memory and construction of the 'Other'.

\section{Before The Visit}

Comparing Bruck's autobiography with accounts of other survivors from the same village and with the same background, including Bruck's own sister, illustrates not only how Jews experienced rural anti-Semitism before 1944, when the deportations happened in Hungary, but also the complexities of remembering these events. In the first part of her autobiography, Who Loves You Like This, Bruck describes the poverty of her family, together with the chilling atmosphere of increasing anti-Semitism in Tiszakarád, as reflected in her account of how non-Jewish villagers harassed and even beat up their Jewish fellow citizens. "I looked at the land I loved, the houses and the trees that were dear to me. I watched the faces of the people who passed me in the street. I wanted to ask, 'You, too? All of ypu hate me?"'(Bruck 2001,13-14).

They chronicle repeated verbal abuseand harassment from local authorities such as the gendarmerie, which stepped up the frequency of checking papers and fining Jewish villagers for insignificant or even invented violations after 1938 in their accounts. The survivors who provided oral history accounts agreed that newspapers and radio broadcastsimported themes that contributed to the intensifying hatred of Jews in the village during this period(VHA Ignác Grosz and Irma Nemény).

Bruck's sister, Adel (VHA Adel Taub), for instance, recalled:

The people here were not bad people, they were not that anti-Semitic, or at least they did not show it () they broke my brother's head when he went to fetch water and called him a dirty Jew, there were incidents like this.... but 
usually they did not show it, they were not as bad as in the village of my husband.

In contrast, Edith Bruck, the well-known writer did not recall much interaction at all between Jews and non-Jews, probably as they were isolated as they were very poor. However, an equally poor survivor for the question raised by VHA interviewer, "Did you have non-Jewish friends?" one of the survivors from the same village, Biri Goldstein's answer was: "I talked to them but not especially"(Shoah Foundation Visual History Archive Testimony by Biri Goldstein).

Her sister Adel Bruck remembers differently, that Jewish children often played with non-Jewish girls, while Jewish boys studied in ethno-religious isolation in the local religious school, the cheder (VHA Adel Taub).

In post-war accounts, Edith Bruck did not address the question of whether her family could have anticipated the deportations in the spring of 1944. Other survivors from the village who had contacts with the non-Jewish majority, learned ahead of time that the deportation would talke place on the day following Easter, 9-10th April 1944 (VHA Ignác Grosz). From Bruck's autobiography, we learn that the Hungarian gendarmerie conducted the deportation with zero resistance from Hungarian fellow villagers who did not assist the Bruck family orother lewish families. Another survivor, Ignác Grosz, however, recalled that a friend had previously offered to hide Grosz's personal possessions, but he was unable to approach the house when the, time came due to the cordon of Hungarian gendarmes around the housedVHA Ignác Grosz) (Other survivors from Tiszakarád remember that non-Jewish villagers offered them food while they were in the synagogue:

They brought milk and bread. Women were wiping their tears with their aprons when we were taken from the village, but then that passed away and they were taking everything. My [elder. A.P.] sister's dowry. When I returned, I have not found anything from it. (VHA Adel Taub)

Other survivors mentioned that the villagers themselves were terrorized by the Hungarian gendarmerie and therefore they did not even dare to look at the Jews when they were deported from the synagogue (VHA Erzsébet Grosz and Biri Goldstein). 
Edith Bruck presented a simplistic dichotomyof Hungarian-Jewish relations in her village in her autobiography and also in the interviews she gave after becoming an internationally acknowledged author. This narrative position strengthened her case of being a 'moral witness'. Her visits in Tiszakarád were then represented as tests of the Hungarian-Jewish relationship which were more complex than she portrayed them in her work.

\subsection{The Visit(s) as they happened}

Bruck's first visit to Tiszakarád after her deportation happened right after the war in 1945 and was short-lived. After being liberated from the Auschwitz concentration camp, she returned skeleton thin to her home village to locate surviving family members. Such quests were hardly unique: two other Tiszakarád survivors recounted similar stories of their return in their oral histories. Ignác Grosz, for instance, lived in the house of a non-Jewish villager in Tiszakarád until he married upon his return, and later left Hungary for Israel. Irma Nemény warmly recalled her return and finding a several individuals who had worked for her father, the rich agricultural entrepreneur. During the first visit to Tiszakarád, Edith Bruck recounted how she was harassed by the village inhabitantswho fad not expected her to return at all. This is in line with post-war, post-Shoahland anti-Semitism which resulted in a series of pogroms across Hungary(Pető 2009, 240-253).

Like other survivors, Bruck, didnot wait to experience more violence and moved to Slovakia, laterimmigratedto Israel. This period is also featured in a recent movie, Anita B, produced and directed by Roberto Faenza in 2014.

She spoke about this decision in an interview:

I went back to Hungary, to my village right after the war, and almost all the neighbors were driven away. They [villagers. A.P] were afraid that we would take back their poor things, we would punish them for what they did, because there was Communism and the accusation was that the Jews brought Communism there.(McClinn 2002, 35)

However, another story emerges from her sisterAdel's account: 
[...] went to the house and collected what I could. The stove was taken away, I brought it back. The wardrobe. [She brought back the wardrobe. A.P.] Somebody lived in the house but left. I cleaned the house and we lived with my sister [Edith Bruck. A.P.]. My sister did not want to stay in [Tiszakarád. A.P.], so she left for my elder sister to Debrecen [...] my [return. A.P.] was nothing special. The neighbors were happy or at least they pretended that they were happy. One of them said that this was taken away by that person that was taken away by somebody else. As I said I got back the stove, the wardrobe, and some other items. Whatever I could not, that I could not recover. (VHA Adel Taub)

Other survivors who lived outside of Hungary when they were interviewed by the Shoah Visual History Archive, also only spoke about the tedious and painful process of recovering their own property from the villagers (VHA Erzsébet Grosz and Ignác Grosz) during the post-war period. The survivors, like Adél Bruck, were not convinced by the authenticity of the joy villagers expressed upon the return of the Jewish population, but they tried to start a new life in the village, possibly again in their own homes.

Bruck's second visit happened in 1962 when she returned to the village together with her Italian husband. According to her testimony, she was harassed by the villagers and asked for money as they now recognized her as a rich foreigner. In the movie, The Visit,recorded in 1982, she described this visit with horror and referring to it as her'first' visit to Tiszakarád after her deportation. She probably did this in order to omit from her memory the more painful initial visit in 1945. The first visit of Edith Bruck to her home village happened when she was just one of the several 'moral witnesses' before she became famous. In the film she describes how in 1962, the village women surrounded her and demanded that she pay her father's debts. "That was the last big slap on my face" - she said in the film about how her family was remembered by their neighbors even twenty years after (The Visit, transcript 22). The only source we have about what happened during this second visit are the interviews with Edith Bruck. As she constructed her fictional self-image with this film, whether this encounter really happened is not relevant as we have no way to check it. 


\subsection{The Visit filmed}

Bruck wanted to break the silence in Hungary about the deportation of Jews and the plunder ofJewish property with her 1982 film, and she based it on her own script. She was proud of the final result:

The film was a great success - produced by the state film industry. A film which called the Hungarians' attention to themselves, to their own history and to their treatment of their Jewish citizens. In the schools then the students were taught that Hungary was allied with the Soviet Union during the Second World War and not with the Nazi fascists. The film for me was a terrible ordeal but it was my duty to make it, to uncover the truth of the facts and to reawaken drowsy or self-deluded consciences. (McClinn 2002, 35)

The reception of the film was neither a success nor did it accomplish a coming to terms of Hungarians' treatment of their Jewish neighborsin the anti-fascist framework of remembering when all victims were considered equal. When I interviewed Edith Bruck in Rome she again spoke of this film in relation to her self-representation as a 'moral witness':

There is something that I get to Hungary, and the whole country is watching the movie three times [...] this happened the first with my movie. With the movie I made. The movie made about me. Through that movie it surfaced what happened in Hungary. Everybody was silent. [...]They were silent in Hungary about what happened, because they [Hungarian Jews. A.P.] were a part of what happened, they were guilty. The Jews were as silent as the non-Jews. (Pető 2002)[ifalingmine. A. I P ]

Her uncertain formulation: "my movie. With the movie I made. The movie made about me", highlights the political problems with the film and that is topic of this paper. Hungarian communist cultural norms in 1982 could not accept a film made about Hungarian rural anti-Semitism, collaboration, and plunder of Jewish property. Consequently, the Hungarian authorities used different strategies to prevent this from happening. Bruck who wanted to play the role of the 'moral witness' was vulnerable to these strategies and was easily manipulated. She was particularly vulnerable as she was alone in this process. 


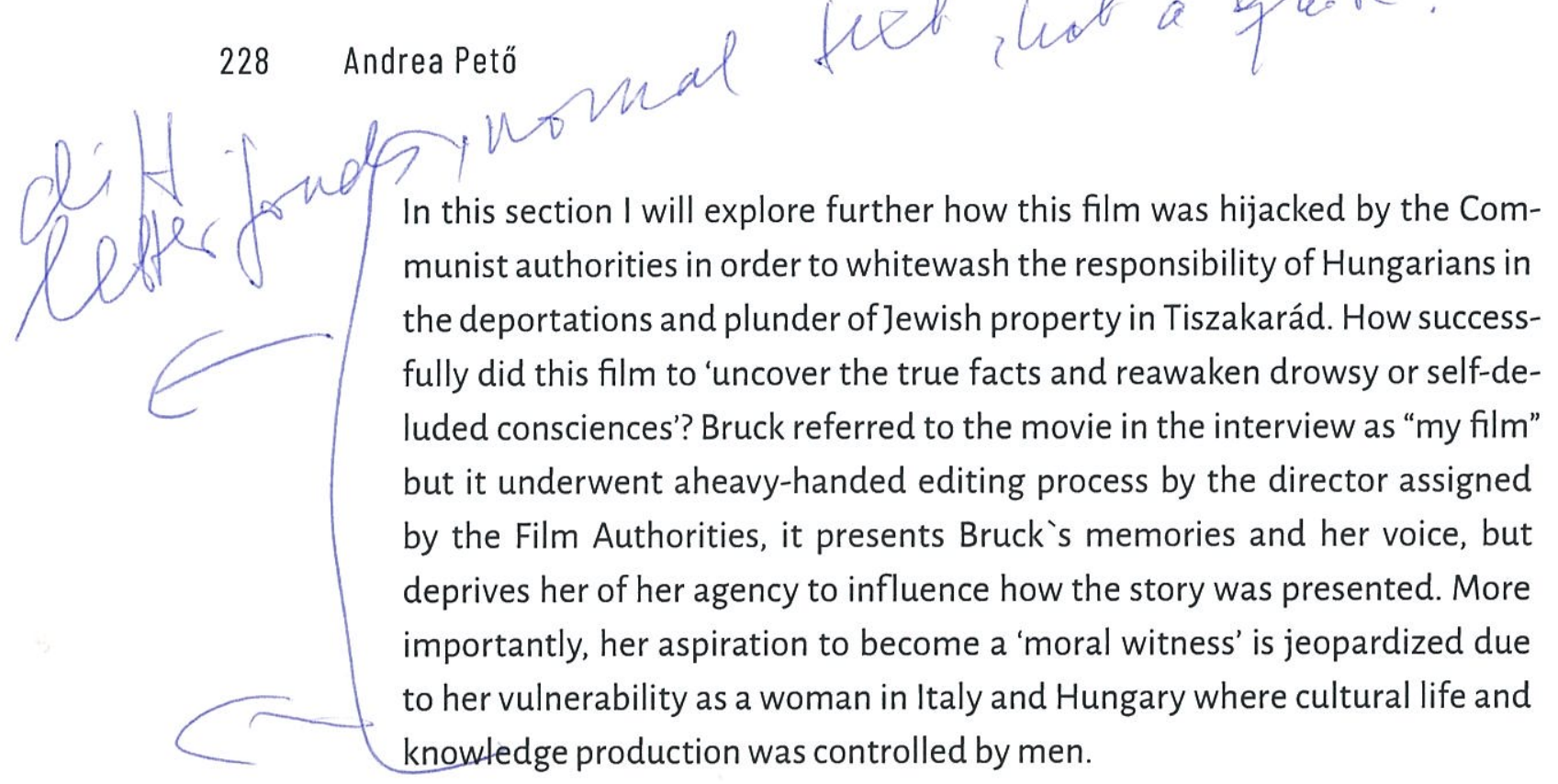

Making a Holocaust movie in communist Hungary in the 1980s was not an easy endeavor, especially not when the producer was an Italian citizen. Recently, the film's director, László Révész (1942), gave two interviews about the politics impacting his production of The Visit. In one of them, he spoke of the constraints set by the Communist state authorities on the original script of the film by Bruck. "Then the Main Authority of Films 'the omnipotent Main Directorate of Films' (Filmföigazgatóság) had a final word on each and every film made in communist Hungary"-said Révész and discovereed that "the script by Edith is anti-Hungarian, shows the villagers as too racist eyen anti-Semites, therefore they do not support the making of the film" (Dunavölgyi 2016).

After the original script of the film written by Bruck was rejected, the film making process was also sabotaged by pushing her to sign an unfavorable contract with the Hungarian Film Factory (Filmgyár). By now it is impossible to reconstruct the process as no paper trail is available in the archive. With this signature, Bruck commissioned all rights to actually produce the movie to the Hungarian Film Factory, a political move by the Hungarian state as it determined the movie would become part of communist cultural policy. It is understandable that she wanted to have her film made in and by Hungarian state, the state which once sent her to Auschwitz. László B. Révész, who had very good personal relations with this state institution, volunteered or rather jumped at the opportunity to make a documentary film about Bruck's visit in Tiszakarád himself. He was considered politically reliable enough by the Communist authorities to make the controversial film. Révész's decision was possibly not independent from the fact the film was granted a lav- 
ish budget as they it would create a good public image of Hungary in the 'West' as far as the country's participation in the Shoahwas concerned. This filming budget included two state financed trips to Rome for planning and filming at a time when state sponsored business trips to the other side of the Iron Curtain were rare. The aim of the Communist authorities was to avoid a recording of an allegedly 'anti-Hungarian' film by all means. Révész himself came up with a compromise which gave the impression to Edith Bruck that she was somewhat in charge of the process of making the film but the final cut was made by the director under strict control of the authorities. Révész collaborated with the authorities to neutralize the film.

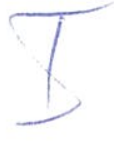

By then we were friends with Edith and it was my idea that with a twist we can make the film: a film about Edith Bruck, and in that somehow she can record that visit she originally planned to film in the original movie. (Szekfü 2015, emphasis A.P.)

Bruck signed the contract with the Hungarian Film Factory because she believed in what she was told. Namely that there would be two films produced in parallel: Bruck making the film of her own and Révész's parallel film about Bruck making her own movie. This arrangement was aimed to calm Edith Bruck, and to avoid an international scandal, as Bruck by then was a well-known writer and artist in Italy. The Hungarian authorities wanted to avoid her using her press contacts to make public statements about how her film was being sabotaged.

By the end, only one film was made by Révész as he was commissioned as the only director by the Hungarian Film Factory. He had all the power not only to decide how many cameras were set up and where. It is clear that his editorial decisions were driven by political consideration: the communist cultural politicians were screening different versions of the film to different focus groups and adjusted the film according to the feedback they have received(Szekfü 2015). Making the film was not an easy task, Révész still remembers how difficult it was for him when "as a director I had to say no" to Edith Bruck(Szekfü 2015).It is clear also from the afterlife of the story that Bruck was a tough negotiator therefore the film did not become what it actually meant to be: a propaganda tool. However, with this movie made by the Hungarian state, Bruck lost her control over 'her' film no matter that the film

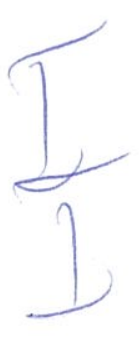


which was expected to record her own life story. She spoke about her disappointment quite openly to me during an interview in 2002 :

They said they will make a movie about me and they commissioned it to László Révész. He did the movie but there were some problems. At the cutting they said the film was damaged by light that is the reason why that part is missing from the movie. I said I do not believe it. They wanted to keep something secret, there was censorship. (Pető 2002)

It is particularly difficult by now to reconstruct what parts of the film were deleted due to censorship. Based on the interviews, problematic flash points emerged during the film making process, each one connected with the representation of the responsibility of non-Jewish Hungarians in the Shoah and the memory of the Shoah. First, the Jewish cemetery in Tiszakarád was totally neglected by the authorities, but it was renovated quickly before the arrival of the film crew. The poor family of Edith Bruck moved in to this new house in 1944 with hope and pride, as she describes it in her autobiography: Who loves you like this. Second, Edith Bruck's family home had been abandoned and ruined after the family left the village. The house was significant to Bruck's sister, Adel Taub, who, in her Shoah interview, wanted to present a photo of the family home, but encountered apparent disinterest on the part of the interviewer, who favored a poster advertising The Visit focusing on Edith Bruck's return to Tiszakarád. Since Edith Bruck photographed the house on her visit in 1962, the issue was even more complicated; the local authorities rightly assumed that she expected to see the same house again in 1982. At the end of each VHA interview the interviewees showed photos of their choice therefore we know how important the house was to the sister of Edith Bruck. The Communist authorities intervened by informing the villagers who owned the Bruck's former home they would demolish it after the film crew left Tiszakarád. Thisway, the house was be picturesquely filmed as a symbol of absence and destruction. The third critical point was a staged meeting with villagers, following tensions from previous visits as well as Bruck's remarks about the inherent anti-Semitism of the villagers in her autobiography. Director Révész later explained that the villagers were informed about the visit by authorities who shadowed the visit and that the villagers' reactions were carefully choreographed. As the cameras rolled, the villagers, apparently spontaneously, prepared a meal to celebrate the return 
of the village daughter-Bruck. In reality, it was carefully choreographed while Bruck has taking a $300 \mathrm{~km}$ taxi ride from Budapest to Tiszakarád. On the day of filming, one camera was already set up in the main square to show the taxi slowly arriving in Tiszakarád. Another camera recorded Edith Bruck, who wore a microphone. The script deliberately confuses past and present as the taxi approaches the village, Edith Bruck enthusiastically and repeatedly exclaims: "I know this, I live here" (The Visit, transcript 25).

She uses present tense as if she had never left the place as a proof that her testimony is in making. This third visit to Tiszakarád serves as a normalization of memory, or as the meta-visit while creating a presentable version of the Jewish-Hungarian relationship in Tiszakarád to the viewers of the documentary film.

The motion of the camera tellingly informs the viewers that the 'spontaneous' interest of the village inhabitants was carefully planned, as well as their emotional outbursts. After the arrival of the film crew in the village women gathered around Bruck, kissing her, their tears flowing as if a long lost daughter had arrived unexpectedly. The choreographed performance depicted how loved she was in the village and how happy her neighbors were to see her again, a powerful part of the film.

The only sign that this relationship between Bruck and the villagers was not always idyllic is when an unidentifiable woman brings a worn tin pot to Edithand says:"That was sent to you by Aunt Vali, this was your pot, so please accept it with love." (The Visit, transcript 41).Accepting a worn tin pot stolen forty years earlier from the house of her murdered mother by a stranger with love would be a very difficult gesture in reality. Bruck bursts into tears as she looks and holds it. Here her return to her place of birth becomes a process of self-victimization. She weeps and sings Hungarian songs with the villagers, as she eats their food and accepts their hospitality, as if she were being welcomed back into a fold from which outside forces-not the villagers-had expelled her. As Bell Hooks pointed out the case of Tony Morrison "[she] constructs a portrait of the black female spectator; her gaze is the masochistic look of victimization"(Hooks 1999, 312). Edith Bruck was made an author by the Shoah for her artistic work and defined the space for discussing the Shoah "both as sanctuary and as a place of bonding." According to psychoanalytical studies, having "transitional space" is essential to ever recover from a trauma (Laub 1992, 58). The film, The Visit also serves as a space for recovery and a space for 'moral witnessing' for her. 
The movie is obviously staged by the Communist authorities as a "movie about Bruck and her survival-not about Hungary during the Holocaust" (Szekfû 2015). From several hours of footage recorded in the village only $18 \mathrm{~min}$ utes made it into 76-minute film after careful editing, test screenings and approval from different authorities needed to be screened in public. The Visit was also screened for the local village authorities prior to being released. They allegedly openly protested as the film overemphasized the poverty of the village which might have contributed to the visit being a minimal part of the film. What else has been cut we will never know. The rest of the film is filled with interviews of Hungarian intellectuals about Edith Bruck and interviews with Bruckherself.

Bruck`s ordeal did not end here. The film appeared on television, but then disappeared from public circulation. It received mixed reviews at the annual documentary film competition in Hungary. The chief jury member, influentialCommunist literary critic, István Király (1921-1989) criticized the film's "baroque elements".This was probably code for the overflow of emotions present in the film.Bruck's only weapon was her international acknowledgement as an Italian writer which proved to be not enough against the strong will of selective silencing by Communist cultural policy. She wanted to be a proud protagonist of a movie so she applied self-censorship for quite a while. Bruck first spoke about the film this way during the interview to me. Bruck's effort to contribute to the process of remembrance brought very mixed results. Her third and best known visit generated a highly sanitized, feel-good narrative of deportation and survival of Jews from Tiszakarád, effectively repressing the trauma of her first return to her home village.

\subsection{The Visit in 2015}

The film also had an afterlife. László Révészwas honored in 2015 in a celebration meant to highlight Hungarian documentary film making in Budapest. He chose The Visit as his best film to be screened, followed by a Q\&A. During this, he skillfully shifted the discussion to talk about Edith Bruck's difficult personality and her identity problems. He shared that Fedith Bruck had an abortion resulting in infertility in the 1950 (Szekfü 2015).This aspect of Bruck's life story is missing from her different interviews and also from her autobiography. This intimate and tragic story told by the director who several times labelled himself as "her friend", discredits her as an artist and a

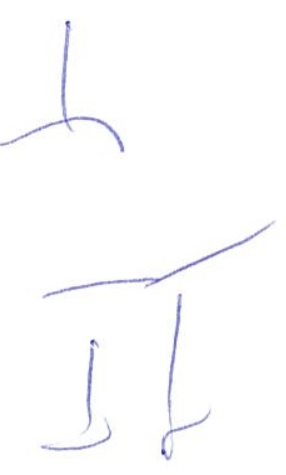


writer and creates the image of a troubled femininity for the public which is already prejudiced against female artists. Bruck as a feminist activist herself also spoke about her abortion only oncein the numerous interviews she gave as a result of violence:

That abortion left an indelible mark inside me both for the circumstances and for my utter ignorance of sex or pregnancy. Auschwitz, which conditioned in every sense my existence, my way of seeing things, of feeling, of how this world lives, is to blame for that tragedy as well. (McClinn 2002, 35)

In the male centered Hungarian cultural scene, Bruck was out of place as a founder of a feminist theatre and a celebrated member of the cultural circles in Rome. Révész also called Bruck "militant" for fighting against discrimination, attempting to discredit her further:

She is obviously a strong personality, being hurt in different ways, and bearer of different conflicts, but a very strong personality. If that does not hurt her from distance: $n$ aggressive, assertive personality. (Szekfü 2015)

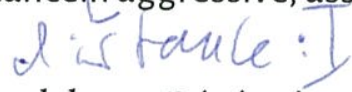

The event to celebrate Révész in 2015 was demonstrative of the negative attitudes in Hungary about Bruck, by both Révész as well as audience members. One of the women in the audience blamed Bruck for the abandonment of her home: "She did not take care of that house. This woman was not penniless, maybe political problems prevented her to help the village." (as quoted in Szekfü 2015). This indicates the expectation that Bruck had a duty to support the village even though her family and her were offered no protection during the war and their property was looted after they were deported and escaped.

Moreover, Révész revealed during the evening in 2015 that he had proudly fought for one sentence, which at the end, remained in the film against the will of the Communist censors, further aggrandizing himself. This sentence was said by one of the villagers during the celebratory and reconciliatory meal when Bruck was in Tiszakarád: "What a pity that they have not started with the gypsies but with you." It was uttered in 1982, a time in which several Roma families had moved into the village. To provide context, this period marked the beginning of worsening economic conditions innorth-easternHungary and the beginning of ethnic conflict between Hungartian and Roma. Moreover, the sentence reveals two other things. The first is that it was 'they'

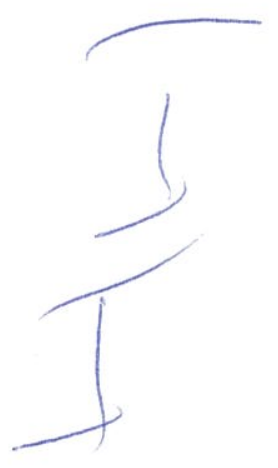


who executed the deportations, not the Hungarians, and that regardless of if they had started with the Romani, the Jews would still have been next. It also highlights the deeply held anti-Roma racist beliefs shared and approved by decision makers over time.

\section{Conclusion}

The story of Edit Bruck`s visits to her home village in Tiszakarád serve as a case study to prove the complexities of shaping memories of the Shoah. Edith Bruck set for herself as an artist the role of a 'moral witness'. According to Margalit, somebody can be considered as 'moral witness' if s/he acts consistent with clear moral aims (Margalit 2004,151) while taking personal risks (Margalit 2004,157).

Bruck herself in her literary works is eager to take the position of the 'moral witness':

I think, I believe that I am not only writing for myself, and what I am writing also concerns the others, because I am writing about topics, which unfortunately concern others as well. Because some are still persecuted, some are being oppressed, and there is still racism, and unfortunately I think this topic will never be exhausted. (The Visit, transcript 6)[...] Do not forget that every day there is a lager somewhere, do not forget that. (The Visit, transcript 17, italics A.P.)

Being a 'moral witness' is particularly difficult for a woman who seeks to break out from convenient gender stereotypes(Pető/Hecht/Krauska 2015).In the long run, no matter that Edith Bruck wanted to present herself as a 'moral witness', in Hungary by 2015 she was portrayed as an exceptional and strange woman with loose morals, who was expected to take responsibility for why her family house owned by others was destroyed. Her position during the past decades moved from a celebrated and successful Italian writer to a troublesome, infertile woman and can be illustrated by the lack of integrating a female survivor as a 'moral witness' in collective memory in Hungary. This process described in this paper provided a step towards revising the memory of the Holocaust in Hungary. And in a wider context, it demonstrates the difficulties homogenous societies have when an 'Other' who has been 
chased away, reappears, in this case on multiple occasions over time. The different acts of discrediting Bruck based on her ethnicity and gender which are intrinsically related to each other are demonstrated through a number of artistic works, personal interviews, and chronicles of events in Hungary over the decades after WWII. Thus, they may serve as good illustrations for how 'othering' is often based on intersections of different categories of inequality. Specifically, it could be argued that after the Shoah anti-Semitic accusations can no longer serve as an acceptable reason for discrimination, 'troubled feminity' is used as a thought-terminating cliché in their place.

\section{References}

Adalgisa, Giorgio (1999): Strategies for remembering: Auschwitz, mother and writing in Edith Bruck. In: Peitsch,Helmuth/Burdett,Charles/Gorrara, Claire (eds.): European Memories of WWII. New York/Oxford, 247-255.

Balma, Philip (2007): Edith Bruck's experience in Italy: Publishing, cinema, and the thematic ghetto. In:Speelman, Raniero/Jansen, Monica/ Gaiga, Silvia (eds.):Contemporary Jewish Writers in Italy a Generational Approach.Italianistica Ultraiecina 2.Utrecht, 108-113.

Balma, Philip (2014): Edith Bruck in the Mirror. Fictional Transitions and Cinematic Narratives.West Lafayette Indiana.

Bruck, Edith (1999): Signora Auschwitz. Il dono della parola. Venezia.

Bruck, Edith (2001): Who Loves You like This. Philadelphia.

Clementi, Federica K. (2008): Re-centering the Mother: Shoah Autobiography in Ruth Kluger, Edith Bruck, Sarah Kofman. Dissertation. New York. Dunavölgyi,Péter (2013, $6^{\text {th }}$ of March): Interview with Laszló B. Révész. In filmeshaz.hu. http://www.filmeshaz.hu/mtvtortenet/interjuk/int_B/int_ BReveszLaszlo.htm(04.11.2018)

Faenza, Roberto(dir.):Anita B., Rai Cinema 2014, film.

Hooks, Bell (1999): The oppositional gaze. In: Thornham, Sue (ed.):Feminist Film Theory: A Reader. Edinbourgh, 307-320.

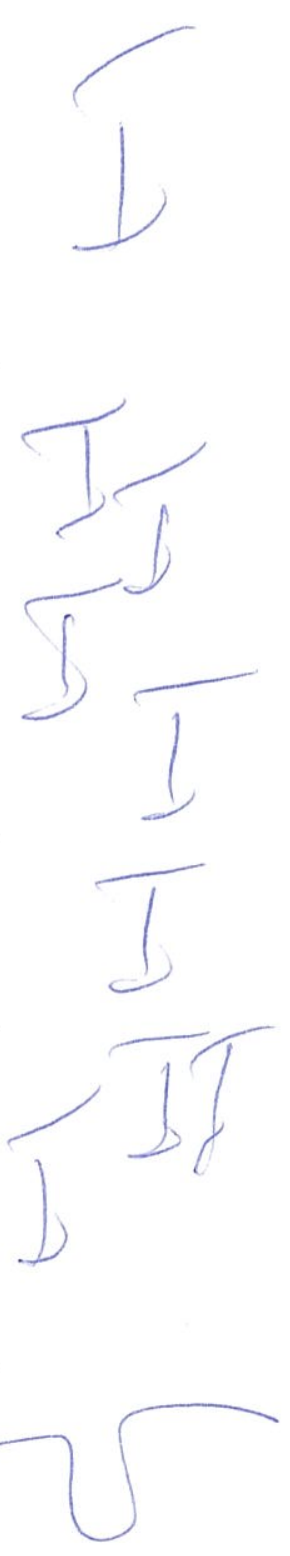

Laub, Dori (1992): Bearing witness or the vicissitudes of listening. In: Felman,

Shoshona/Laub, Dori(eds.): Crises of Witnessing in Literature, Psychoanalysis and History. New York, 57-74.

László B. Révész (dir.): A látogatás (The Visit), 1983, film.

Margalit, Avishai (2004): The Ethics of Memory. Harvard. 
McGlinn, Marguerite (2002): Who Loves you Like This. A Holocaust Memoir by Edith Bruck. Curriculum Guide. Philadelphia. https://cdn.shopify. $\mathrm{com} / \mathrm{s} /$ files/1/0446/9005/files/bruck_guide.pdf(04.11.2018)

Pető, Andrea (2002, 2nd of January):Personal interview with Edith Bruck, Rome, Italy.

Petô, Andrea (2007): In transit: space, people, identities. Intermezzo. In: Passerini, Luisa/Lyon, Dawn/Capussotti, Enrica/Laliotou, Ionna (eds.): Women Migrants from East to West. Gender, Mobility and Belonging in Contemporary Europe. Oxford/New York, 243-251.

Petô, Andrea (2009): About the narratives of a blood libel case in post shoah hungary. In: Vasvari, Louise/Tötösy de Zepetnek, Steven (eds.): Comparative Central European Holocaust Studies. West Lafayette, 240-253.

Petô, Andrea (2013): How to use the shoah foundation's visual history archive for teaching at the graduate level - a methodological and theoretical reflection. In: Kovács, Andras/Miller, Michael (eds.): Jewish Studies at the CEU. 2009-2011. Vol. 7. Budapest, 205-211.

Petô, Andrea (2019): 'Non-Remembering' the Holocaust in Hungary and Poland. In: Guesnet, Francois/Lupovitch, Howard/ Polonsky, Antony (eds.):Polin. Polins Studies jn Polish Jewry. Vol. 31. Poland and Hungary Jewish Realities Compared.Liverpool, 2019, 471-480.

Petô, Andrea/Hecht, Louise/Krauska, Karolina (eds.) (2015): Women and Holocaust: New Perspectives and Challenges.Warsawa.

Pető, Andrea (2016): Digitalized memories of the Holocaust in Hungary in the visual history archive. In: Braham, Randolph/Kovács, András (eds.): Holocaust in Hungary 70 Years after, Budapest, 253-261.

Shoah Foundation Visual History Archive (VHA): Interviews with Testimonies Goldstein, Biri (19069), Grosz, Erzsébet (3792), Grosz, Ignác (3803), Nemény, Irma (4417), Taub, Adel (42036).

Szekfü, András (2015): László B. Révész: "A látogatás". 100 magyar dokumentumfilm. In: Youtube.com.https://www.youtube.com/watch?v=dJ5 CVunrQik (04.11.2018)

Villa,Cristina (2007): Perché la Shoah talvolta parla italiano? La letteratura italiana delladeportazione razziale nelle opere di Edith Bruck, Springer Elisa.In:Speelman, Raniero/Jansen, Monica/Gaiga, Silvia (eds.):Scrittori italiani di origine ebrea ieri e oggi: un approccio generazionale, Italianistica Ultraiecina 2. Utrecht, 97-105.
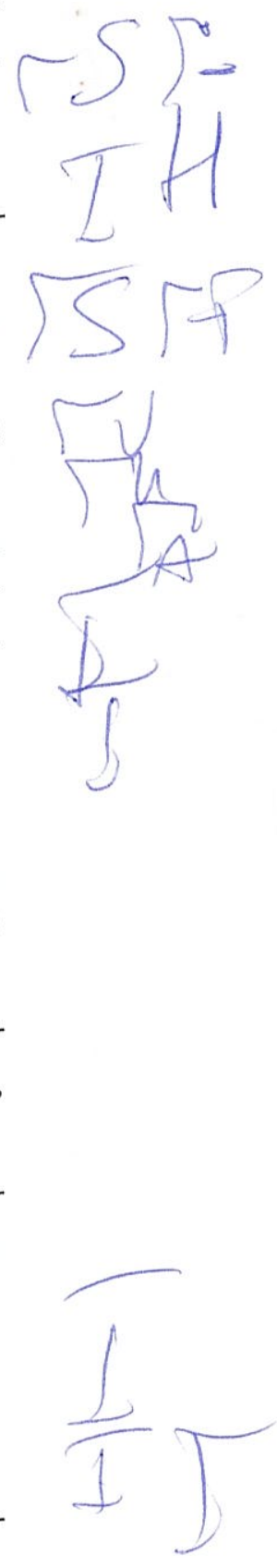